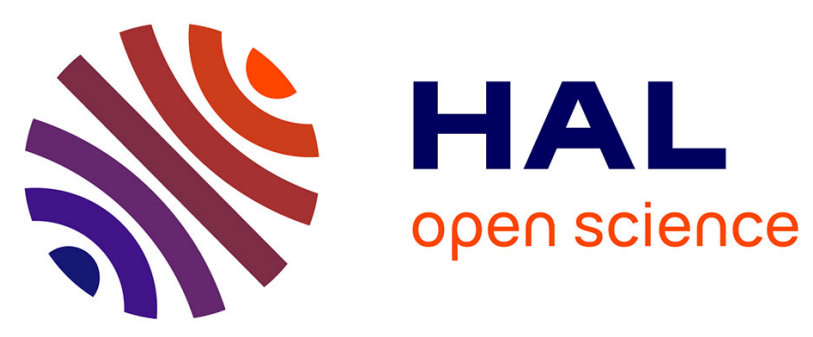

\title{
Detection of illegal treatment of barrows with nandrolone ester; effects on growth, histology and residue levels in urine and hair
}

Maria Groot, Johan Lasaroms, Eric van Bennekom, Thijs Meijer, Ester Vinyeta, Jan-Dirk van Der Klis, Michel Nielen

\section{To cite this version:}

Maria Groot, Johan Lasaroms, Eric van Bennekom, Thijs Meijer, Ester Vinyeta, et al.. Detection of illegal treatment of barrows with nandrolone ester; effects on growth, histology and residue levels in urine and hair. Food Additives and Contaminants, 2012, pp.1. 10.1080/19440049.2011.647097 . hal-00783341

\section{HAL Id: hal-00783341 \\ https://hal.science/hal-00783341}

Submitted on 1 Feb 2013

HAL is a multi-disciplinary open access archive for the deposit and dissemination of scientific research documents, whether they are published or not. The documents may come from teaching and research institutions in France or abroad, or from public or private research centers.
L'archive ouverte pluridisciplinaire HAL, est destinée au dépôt et à la diffusion de documents scientifiques de niveau recherche, publiés ou non, émanant des établissements d'enseignement et de recherche français ou étrangers, des laboratoires publics ou privés. 


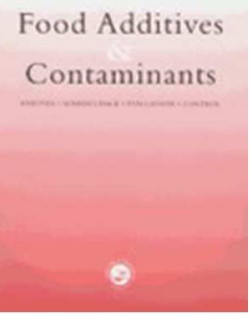

\section{Detection of illegal treatment of barrows with nandrolone ester; effects on growth, histology and residue levels in urine and hair}

\begin{tabular}{|c|c|}
\hline Journal: & Food Additives and Contaminants \\
\hline Manuscript ID: & TFAC-2011-451.R1 \\
\hline Manuscript Type: & Original Research Paper \\
\hline Date Submitted by the Author: & 30-Nov-2011 \\
\hline Complete List of Authors: & $\begin{array}{l}\text { Groot, Maria ; RIKILT Institute of Food Safety, The Netherlands, Bioanalysis } \\
\text { and Toxicology } \\
\text { Lasaroms, Johan; RIKILT - Institute of Food Safety, Analysis and } \\
\text { Development } \\
\text { Van Bennekom, Eric; RIKILT - Institute of Food Safety, Analysis and } \\
\text { Development } \\
\text { Meijer, Thijs; RIKILT - Institute of Food Safety, Analysis and Development } \\
\text { Vinyeta, Ester; Schothorst Feed Research B.V., } \\
\text { Van der Klis, Jan-Dirk; Schothorst Feed Research B.V., } \\
\text { Nielen, Michel; Wageningen University, 3Laboratory of Organic Chemistry; } \\
\text { RIKILT - Institute of Food Safety, Analysis and Development }\end{array}$ \\
\hline Methods/Techniques: & Chromatography - LC/MS, Bioassay, Chromatography - GC/MS \\
\hline Additives/Contaminants: & Drug residues - hormones \\
\hline Food Types: & Animal products - meat \\
\hline Abstract: & $\begin{array}{l}\text { Abstract } \\
\text { To evaluate the effects of } 17 \beta-19 \text {-nortestosterone (17ßNT) treatment of } \\
\text { barrows on residue levels and on growth results, an animal experiment was } \\
\text { conducted. Five barrows were treated } 3 \text { times during the fattening period } \\
\text { with } 17 \beta N T \text { phenylpropionate (Nandrosol, nandrolone phenylpropionate } 50 \\
\mathrm{mg} / \mathrm{ml}, 1 \mathrm{mg} / \mathrm{kg} \text { BW). Another } 5 \text { barrows were not treated, and } 5 \text { boars } \\
\text { (not treated) were kept as a positive control. Boars and treated barrows } \\
\text { showed } 13 \% \text { and } 9 \% \text { better growth than not-treated barrows, leading to } \\
\text { mean final body weights of } 121.6,117.8 \text { and } 109.0 \mathrm{~kg} \text { respectively. } \\
\text { Moreover the bulbourethral glands of the treated barrows were } 3 \text { times } \\
\text { heavier than the not-treated barrows. The histology of the prostate and } \\
\text { bulbourethral gland of the treated barrows was comparable to the boars, } \\
\text { whereas the control barrows showed atrophic glands. } \\
\text { Levels of } 17 \beta N T \text { ester in hair from treated barrows were high, whereas }\end{array}$ \\
\hline
\end{tabular}




\section{SCHOLARONE ${ }^{\text {M }}$ \\ Manuscripts}

boars and non-treated barrows did not show levels above LLQ. It is concluded that analysis of hair can provide a method for detection of illegal treatment with $17 \beta N T$ ester in barrows. The size of the bulbourethral gland can be used for screening in the slaughterhouse.

\section{Manuscripts}


1 Detection of illegal treatment of barrows with nandrolone ester;

2 effects on growth, histology and residue levels in urine and hair

4 Groot $^{1 *}$, M.J., J.J.P. Lasaroms ${ }^{1}$, E.O. van Bennekom ${ }^{1}$, T. Meijer ${ }^{1}$, E. Vinyeta ${ }^{2}$, J.D.

$5 \quad$ van der Klis ${ }^{2}$ and M.W.F. Nielen ${ }^{1,3}$

6

$7 \quad{ }^{1}$ Maria Groot, RIKILT Institute for Food Safety, Wageningen University and

8 Research centre, PO Box 230, 6700 AE Wageningen Netherlands. Email:

$9 \quad$ maria.groot@wur.nl

$10 \quad{ }^{2}$ Schothorst Feed Research, Lelystad, Netherlands

$11{ }^{3}$ Laboratory of Organic Chemistry, Wageningen University, Dreijenplein 8, 6703 HB

12 Wageningen, The Netherlands

13

14 Abstract

15 To evaluate the effects of $17 \beta-19$-nortestosterone (17ßNT) treatment of barrows on

16 residue levels and on growth results, an animal experiment was conducted. Five

17 barrows were treated 3 times during the fattening period with $17 \beta \mathrm{NT}$

18 phenylpropionate (Nandrosol, nandrolone phenylpropionate $50 \mathrm{mg} / \mathrm{ml}, 1 \mathrm{mg} / \mathrm{kg} \mathrm{BW}$ ).

19 Another 5 barrows were not treated, and 5 boars (not treated) were kept as a positive

20 control. Boars and treated barrows showed $13 \%$ and $9 \%$ better growth than not-

21 treated barrows, leading to mean final body weights of $121.6,117.8$ and $109.0 \mathrm{~kg}$

22 respectively. Moreover the bulbourethral glands of the treated barrows were 3 times

23 heavier than the not-treated barrows. The histology of the prostate and bulbourethral

24 gland of the treated barrows was comparable to the boars, whereas the control

25 barrows showed atrophic glands. Levels of $17 \beta N T$ ester in hair from treated barrows 
1 were high, whereas boars and non-treated barrows did not show levels above LLQ. It

2 is concluded that analysis of hair can provide a method for detection of illegal

3 treatment with $17 \beta \mathrm{NT}$ ester in barrows. The size of the bulbourethral gland can be

4 used for screening in the slaughterhouse.

5

$6 \quad$ Corresponding author: e-mail: maria.groot@wur.nl; tel. +31(0)3174280277, fax

$7+31(0) 317417717$

8

9 Key words: 17ß-19-nortestosterone, barrows, hair analysis, histology, urine analysis

\section{Introduction}

12 In male pigs $17 \beta-19$-nortestosterone (17ßNT) is a naturally occurring compound in 13 urine (Poelmans et al., 2005). In boars high levels can be measured but in barrows 14 and gilts only low levels occur. In practice however sometimes high levels of $17 \beta \mathrm{NT}$ 15 are found in urine from barrows. This can be due to cryptorchid animals, having one 16 testicle in the abdomen that produces hormones. But illegal treatment with $17 \beta \mathrm{NT}$ for 17 growth promotion is also a possibility, since 19-nortestosterone (nandrolone) has a 18 long history for abuse as growth promoter in livestock (Rico, A.G., 1983).

19 The use of hormonal substances for fattening purposes in livestock is banned in the 20 EU since 1988 according to Council Directive 96/22 EC (Offic. J. Eu. Comm.,1996).

21 Steroids having estrogenic, androgenic, progestagenic action are forbidden as well as 22 thyreostatics and $\beta$-agonists. Residue analysis on target compounds is carried out by 23 control laboratories to enforce the ban. 
1 Some hormones that were considered as exogenic appeared to occur naturally in some

2 species (Scarth et al., 2009). This applies to 17ßNT which occurs in urine of stallions

3 (Houghton et al., 1994) and in urine from boars (Debruyckere et al., 1990).

4 Boars grow faster and show a better feed conversion with 20 to $30 \%$ less fat than

5 barrows (Field, 1971; Mulvaney et al., 1988; Kudson et al., 1985). Gonadally intact

6 males also have 8 to $15 \%$ greater muscle mass than castrated males (Knudson et al.,

7 1885; Prescott \& Lamming, 1967). In boars, testis and accessory genital glands are

8 normally developed, whereas barrows are castrated at a young age and have atrophied

9 accessory genital glands. Treatment with androgens leads to increase in growth of the

10 seminal vesicles and bulbourethral glands in barrows (Lauwers et al., 1983; Lauwers, 11 1984).

13 In recent years, apart from urine analysis, hair has been analyzed for the presence of

14 esters of anabolic steroids (Sauer et al., 1998; Duffy et al., 2009; Nielen et al, 2006,

15 Stolker et al., 2009). For growth promoting purposes steroid hormones are usually

16 administered with an ester side-chain attached in order to facilitate the steroid

17 reaching the site of activity within the animal's body. Because steroid hormones do

18 not occur naturally in an ester form, detection of intact steroid esters demonstrates

19 illegal administration of these drugs.

21 To investigate if treatment with $17 \beta \mathrm{NT}$ is anabolic in barrows can lead to high levels

22 of $17 \beta \mathrm{NT}$ in urine and hair we treated barrows with $17 \beta \mathrm{NT}$ and compared them with

23 untreated barrows and untreated boars.

\section{Material and methods}


2 The animal experiment was performed by Schothorst Feed Research BV in Lelystad,

3 Netherlands. The trial comprised three treatments according to sex and Nandrosol

4 injection: 1) non-injected boars, 2) non-injected barrows and 3) barrows injected with

$5 \quad 17 \beta \mathrm{NT}$ phenylpropionate (nandrolone phenylpropionate $50 \mathrm{mg} / \mathrm{ml}, 1 \mathrm{mg} / \mathrm{kg} \mathrm{BW}$,

6 Nandrosol, REG NL 10067, Alfasan, The Netherlands). A total of 15 pigs were

7 distributed in 5 replicates per treatment group.

8

9 Experimental animals were grower pigs (Tempo x (Great Yorkshire x Finnish

10 Landrace)) of 60-70 days of age at the start of the experiment and approximately 25

$11 \mathrm{~kg}$ live body weight. Pigs were housed in three separate pens (one pen/treatment) of

$121.80 \times 1.00 \mathrm{~m}$. One spare pig per treatment was also allocated within the experimental

13 pigs and the control barrows and was fed and weighed in case a pen mate dropped out.

14 The animals were fed ad libitum and had free access to water. The animals were fed

15 commercial growing/finishing diets (Arkevaart-Twente Coöperatie, Nijkerk, The

16 Netherlands) commonly used in Schothorst Feed Research in practical conditions.

17 The animals were injected at 19, 47 and 75 days after the start of the experiment and

18 were slaughtered on day 93 of the experiment. Once a month urine and hair was

19 sampled and every two weeks the animals were weighed. Sampling times for hair and

20 urine were day 12,33, 61 and 81, respectively time points 1, 2, 3 and 4. All pigs were

21 delivered to a commercial slaughterhouse at a body weight around 100-115 kg.

22 Treated animals were condemned for destruction. This study was approved by the

23 Ethical Committee of Animal Science Group Lelystad, part of Wageningen

24 University Research Centre, Netherlands. 
1 Histology

2 At slaughter the animals were inspected for gross pathology. Testes (only in boars),

3 prostate and bulbourethral gland were sampled for histological investigation. After

4 weighing the bulbourethral glands, samples of the prostate and bulbourethral gland

5 were immediately fixed in $10 \%$ phosphate buffered formalin, whereas samples of the

6 testis were fixed in Bouin Hollandais fixative, which gives a better morphology. After

7 the usual dehydration series with alcohols and xylol, the tissues were embedded in

8 paraffin. Sections, $5 \mu \mathrm{m}$ thick, were made using a rotating microtome. Sections were

9 stained with heamatoxylin-eosin (HE) according to Mayer (Bancroft \& Stevens, 1990)

10 for routine staining and the prostate and bulbourethral gland were also stained for

11 mucins with the combined Alcian Blue/periodic Acid Schiff (ABPAS) technique

12 staining both acidic (blue) and neutral mucins (red) (Bancroft \& Stevens, 1990).

14 Chemicals

15 The chemicals and solutions used were analytical reagent grade. Water was purified

16 using a Milli-Q system from Millipore (Bedford, MA, USA). 17ßNT

17 phenylpropionate ester and 17ßNT were obtained from Steraloids (Newport, Rhode

18 Island, U.S.A.). The isotope-labeled internal standard $\mathrm{d}_{3}$-testosterone

19 phenylpropionate ester and $\mathrm{d}_{3}-17 \beta \mathrm{NT}$ were custom-synthesized at Wageningen

20 University and Research Centre (Wageningen, The Netherlands). Stock solutions

21 were prepared in methanol at $1 \mathrm{mg} / \mathrm{ml}$. Bondelut LRC-C18 solid-phase extraction

22 (SPE) columns (100 mg and $500 \mathrm{mg}$ ) were from Varian (Harbor City, CA, USA) and

23 ) and IST Isolute $\mathrm{NH}_{2}$ solid-phase extraction (SPE) colomns (100 mg) were from

24 Sopachem (Eke, Belgium). B-Glucuronidase/arylsulfatase (from Helix Pomatia) was

25 obtained from Merck (Darmstadt, Germany). 
$1 \quad$ Sample preparation

2 The hair samples were washed with water and dried for 24 hours in an oven at $60^{\circ} \mathrm{C}$.

3 Then the hair samples were cut in $0.5 \mathrm{~cm}$ pieces using a pair of scissors and $500 \mathrm{mg}$

4 was pulverized in a Sartorius (Goettingen, Germany) model Mikro-dismembrator S

5 ball mill. From each sample two test portions of two hundred milligrams of the

6 pulverized hair were weighed into a plastic tube. Both test portions were spiked with

7 the internal standard $d_{3}$-testosterone phenylpropionate at $10 \mathrm{ng} / \mathrm{g}$. In addition one of

8 the test portions was spiked with $17 \beta \mathrm{NT}$ phenylpropionate at $5 \mathrm{ng} / \mathrm{g}$. Blanks and

9 controls were spiked with the internal standard $d_{3}$-testosterone phenylpropionate at

$1010 \mathrm{ng} / \mathrm{g}$. Control hair samples were prepared by spiking blank hair with $17 \beta \mathrm{NT}$

11 phenylpropionate at $0,2.5,5.0,10$ and $25 \mathrm{ng} / \mathrm{g}$. Digestion of the hair was performed

12 by addition of $2 \mathrm{ml}$ of $25 \mathrm{mM}$ tris(2-carboxyethyl)phosphine (TCEP) and incubation

13 at room temperature for 1 hour. The tube was shaken by using a 'head-over-head'

14 shaker. After addition of $4 \mathrm{ml}$ of methanol, the tube was centrifuged for $5 \mathrm{~min}$ at

$151700 \mathrm{~g}$. Next, $4 \mathrm{ml}$ of water was added and the mixture was applied to a C18 solid-

16 phase extraction (SPE) cartridge, pre-activated with acetonitrile, methanol and water.

17 The SPE-cartridge was washed with $2 \mathrm{ml}$ of methanol/water (60/40 v/v) and eluted

18 with $2 \mathrm{ml}$ of acetonitrile followed by $2 \mathrm{ml}$ of ethyl acetate. The combined eluate was

19 evaporated to dryness under a gentle stream of nitrogen gas at $40^{\circ} \mathrm{C}$ and re-dissolved

20 in $200 \mu 1$ of water-acetonitrile-methanol-formic acid (300/350/350/20, v/v/v/v). $40 \mu \mathrm{L}$

21 was injected into LC-MS/MS system 1.

23 From each urine sample two test portions $(2 \mathrm{ml})$ were transferred into a glass tube.

24 Both test portions were spiked with the internal standard $d_{3}-17 ß-19$-nortestosterone at

$252 \mathrm{ng} / \mathrm{ml}$. In addition one of these portions was spiked with 17ß-19-nortestosterone at 2 
$1 \mathrm{ng} / \mathrm{ml}$. Blanks and controls were spiked with the internal standard $\mathrm{d}_{3}-173-19$ -

2 nortestosterone at $2 \mathrm{ng} / \mathrm{ml}$. The control urine samples were prepared by spiking blank

3 urine with 17ß-19-nortestosterone at 0, 0.5, 1.0, 2.0, 3.0 and $5.0 \mathrm{ng} / \mathrm{ml}$.

4 Prior to hydrolysis, the urine samples were adjusted to $\mathrm{pH} 4.8$. Following the addition

5 of $10 \mu \mathrm{L}$ ß-glucuronidase/arylsulfatase (ready to use, Merck), enzymatic

6 deconjugation was carried out in a water bath at $37^{\circ} \mathrm{C}$ for $16 \mathrm{hr}$. The hydrolyzed

7 sample was applied to a C18 solid-phase extraction (SPE) cartridge, pre-activated

8 with methanol and sodium acetate buffer. The vacuum dried SPE column was eluted

9 with $4 \mathrm{ml}$ of methanol. The eluate was applied to a $\mathrm{NH}_{2} \mathrm{SPE}$ cartridge and the eluate

10 was evaporated to dryness under a gentle stream of nitrogen. The residue obtained

11 was re-dissolved in $225 \mu \mathrm{L}$ (methanol/water $20 / 80 \mathrm{v} / \mathrm{v}$ ) and $200 \mu \mathrm{L}$ was injected into

12 a HPLC system consisting of a vacuum degasser, an autosampler, a binary pump, an

13 UV detector and a fraction collector from Agilent (Santa Clara, California). The

14 fraction where 17ß-19-nortestosterone eluted was collected and evaporated to dryness

15 under a gentle stream of nitrogen and re-dissolved in $300 \mu 1$ methanol/formic acid

$16(0.5 \%)(50 / 250 \mathrm{v} / \mathrm{v}) .40 \mu \mathrm{l}$ was injected into LC-MS/MS system 2.

18 LC-MS/MS systems

19 System 1: The analysis of the hair samples was carried out using a UFLC liquid

20 chromatography system, consisting of a vacuum degasser, an auto sampler and a

21 binary pump from Shimadzu Scientific Instruments (Colombia, MD, USA) equipped

22 with a reversed phase Waters Acquity UPLC BEH C18 analytical column of $100 * 2.1$

$23 \mathrm{~mm}$ and $1.7 \mu \mathrm{m}$ particle size kept in a column oven at $50{ }^{\circ} \mathrm{C}$. The $\mathrm{LC}$ gradient

24 (solvent A, water-acetonitrile-methanol-formic acid (300/350/350/20; v/v/v/v);

25 solvent B, acetonitrile-methanol-formic acid (500/500/20; v/v/v)) with a flow of 0.4 
$1 \mathrm{ml} / \mathrm{min}$ was: $0 \mathrm{~min} 10 \% \mathrm{~B}$; 0.1-2 min linear increase to $70 \% \mathrm{~B} ; 2-8$ min linear

2 increase to $100 \% \mathrm{~B}$; 8-9.5 min $100 \% \mathrm{~B}$. Injection volume was $40 \mu \mathrm{L}$. The UFLC

3 system was connected to a AB Sciex (Concord, Ontario, Canada) mass spectrometer

4 model QTRAP 5500 equipped with an electrospray interface operating in the positive

5 ionization mode. IonSpray voltage was set at $5500 \mathrm{~V}$ and the source temperature was

6 set at $250^{\circ} \mathrm{C}$. Curtain gas, gas 1 and gas 2 were 20,55 and 60 psi respectively. The

7 desolvation gas and the collision-induced dissociation (CID) gas was nitrogen.

8 Entrance potential (EP) for all analytes was 10V. For 17ß-19-nortestosterone

9 phenylpropionate ester the most abundant MRM transition (used for the

10 quantification) was acquired using the following conditions: precursor ion mass $(\mathrm{m} / \mathrm{z})$

11 407.1, Product ion mass (m/z) 105.2 with a Collision Energy of $33(\mathrm{eV})$. A second

12 MRM transition, used for the confirmation of the identity of 17ß-19-nortestosterone

13 phenylpropionate ester, was acquired using the following conditions: precursor ion

14 mass (m/z) 407.1, Product ion mass (m/z) 133.1 with a Collision energy of $25(\mathrm{eV})$.

15 For $\mathrm{d}_{3}-17 ß$-testosterone phenylpropionate the most abundant MRM transition was

16 acquired using the following conditions: precursor ion mass $(\mathrm{m} / \mathrm{z}) 424.2$, product ion

17 mass $(\mathrm{m} / \mathrm{z}) 105.1$ with a collision energy of $30(\mathrm{eV})$.

19 The concentrations of 17ß-19-nortestosteronephenylpropionate in hair samples were

20 calculated using the isotope dilution method and a standard addition of $5 \mathrm{ng} / \mathrm{g} \mathrm{173-19-}$

21 nortestosterone phenylpropionate to each individual sample.

23 System 2: The LC-MS/MS system consisted of a Waters (Manchester, UK) Acquity

24 UPLC model LC system equipped with a Waters model Quattro Premier XE triple-

25 quadrupole mass spectrometer. The mass spectrometer was operated in the positive 
1 electrospray ionization (ESI) mode at a capillary voltage of $2.7 \mathrm{kV}$, a desolvation

2 temperature of $450{ }^{\circ} \mathrm{C}$, a source temperature of $120^{\circ} \mathrm{C}$ and a cone voltage of $30 \mathrm{~V}$.

3 The desolvation gas was nitrogen and the collision-induced dissociation (CID) gas

4 was argon. A Waters Acquity UPLC BEH C18 analytical column of 50*2.1 mm and

$5 \quad 1.7 \mu \mathrm{m}$ particle size was used and kept in a column oven at $40^{\circ} \mathrm{C}$. The gradient

6 (solvent A, water/formic acid 980/20 v/v); solvent B, water-acetonitrile-formic acid

7 (80/900/20; v/v/v)) with a flow of $0.4 \mathrm{ml} / \mathrm{min}$ was: $0-1 \mathrm{~min} 30 \% \mathrm{~B} ; 1-5$ min linear

8 increase to $50 \% \mathrm{~B}$; 5-5.1 min linear increase to $100 \% \mathrm{~B} ; 5.1-7$ min $100 \% \mathrm{~B}$. Injection

9 volume was $40 \mu \mathrm{L}$. For 17ß-19-nortestosterone the most abundant MRM transition

10 (used for the quantification) was acquired using the following conditions: precursor

11 ion mass (m/z) 275.1, Product ion mass (m/z) 109.2 with a collision energy of 25

$12(\mathrm{eV})$. A second MRM transition, used for the confirmation of the identity of 17ß-19-

13 nortestosterone, was acquired using the following conditions: precursor ion mass

$14(\mathrm{~m} / \mathrm{z}) 275.1$, product ion mass $(\mathrm{m} / \mathrm{z}) 145.1$ with a collision energy of $20(\mathrm{eV})$. For $\mathrm{d}_{3^{-}}$

15 17BNT the most abundant MRM transition was acquired using the following

16 conditions: precursor ion mass (m/z) 278.2, product ion mass $(\mathrm{m} / \mathrm{z}) 109.0$ with a

17 collision energy of $30(\mathrm{eV})$.

18

19 The concentrations of $173 \mathrm{NT}$ in urine samples were estimated using the isotope

20 dilution method and a linear calibration curve were constructed for 17BNT by

21 fortifying blank urine aliquots at six different concentration levels (matrix-matched

22 standards, MMS).

23

24 Results and discussion

25 
1 The controlled treatment experiment was performed without problems, the animals

2 were in good health and all animals were suitable for slaughter at the end of the

3 experimental period. Including the spare animals we ended up with 6 treated barrows,

46 control barrows and 5 boars for investigation.

6 An overview of the live weights of the animals is listed in Table 1.

7 Mean live weight at slaughter was $121.6 \mathrm{~kg}$ for boars, $108.9 \mathrm{~kg}$ for barrows and 117.8

$8 \mathrm{~kg}$ for the $17 \beta \mathrm{NT}$ treated barrows. The treated barrows showed a significant $(\mathrm{p}<0.05)$

9 better growth performance than the control barrows, and were not significantly

10 different from the boars. At the facility where the animals were housed it appeared

11 that the last weeks before slaughter there was an increased growth of the treated

12 barrows as compared to the control animals (fig. 1).

13 Insert Table 1 and Figure 1

14

15 These data confirmed our suggestion that $17 \beta N T$ has a growth promoting effect in

16 barrows. In literature the effects of anabolic steroids in pigs are not conclusive: In a

17 series of experiments with implants in pigs, the combination of trenbolone and $17 \beta-$

18 estradiol or $17 \beta$-estradiol and $17 \beta$-testosterone in barrows adversely affected growth

19 rate and feed intake, but the implanted barrows had less fat than the controls (De

20 Wilde \& Lauwers, 1984). Other experiments with castrated males (Van Weerden \&

21 Grandadam, 1976) using implants with trenbolone and 17ß-estradiol showed

22 increased protein deposition and decreased fat deposition in the treated animals.

23 Moreover the carcass weight was $4.5 \mathrm{~kg}$ higher than the controls, and carcass quality

24 was improved and backfat thickness was reduced. In our experiment carcass 
1 characteristics were not investigated because the aim of our experiment was to

2 examine the effects of $17 \beta \mathrm{NT}$ on histology and residue levels in hair and urine.

3 At slaughter there appeared a striking difference in the weight and size of the

4 bulbourethral glands (Table 2), not only between barrows and boars, but also between

5 control and treated barrows. Treated barrows had larger and significant $\left(\mathrm{p}<1 * 10^{-7}\right)$

6 almost 3 times heavier bulbourethral glands than the controls (fig. 2). Increase of the

7 weight of male accessory glands is a well-known effect of androgens in castrated

8 males (Brandes, D, 1994; Booth, W.D., 1890). This increased size could be used as a

9 screening method for illegal treatment of barrows with androgenic hormones in the

10 slaughterhouse.

11 Insert Table 2 and figure 2

12 Histology

13 Histological investigation of the testes of the boars revealed normal spermatogenesis

14 as was expected in these animals. The prostate showed abundant glandular tissue and

15 the bulbourethral glands showed mature glandular tissue (fig. 3) consisting of

16 mucinous acini with secretion of Alcian Blue positive (acidic)secreta. The barrows

17 showed atrophied glandular tissue in the prostate and bulbourethral gland showing

18 immature glandular tissue presenting with rosette shaped alveoli in abundant stroma

19 (fig. 4) and scarce PAS positive secretion. The treated barrows showed an increased

20 amount of glandular tissue in the prostate. The bulbourethral gland presented with

21 mature glandular tissue (fig. 5), which stained blue with Alcian Blue PAS staining.

22 This means that treatment with $17 \beta$ NT induced maturation of the glandular tissue of

23 the prostate and bulbourethral glands in barrows, causing histology resembling that of

24 boars. The results of the histological findings are in accordance with what Lauwers

25 (1984) described as androgen like changes, which he found in barrows treated with 
1 allyltrenbolone. In treated barrows he observed development of the accessory glands

2 in the physiological direction with more glandular tissue in the prostate and increased

3 secretion in the bulbourethral gland and seminal vesicals. In barrows implanted with

4 trenbolone acetate (López-Bote et al., 1994), no changes in carcass weight were

5 observed, but the implanted animals had less fat. They found enlargement of the

6 prostate and bulbourethral gland with increased secretion and cyst formation. Cyst

7 formation was not observed in our experiment, maybe because the animals were not

8 continually exposed to hormones and the difference in androgenic and anabolic action

9 between trenbolone and $17 \beta \mathrm{NT}$.

10 Insert figures 3-5

11 Residue analysis in urine

12 All urines were analyzed for the presence of $17 \beta \mathrm{NT}$. The urine was sampled at 4 time 13 points, corresponding with day 12,33, 61 and 81 of the trial. Levels of $17 \beta N T$ were

14 generally low $(<10 \mu \mathrm{g} / \mathrm{L})$ in barrows and treated barrows, except for one control 15 barrow that had a level of $300 \mu \mathrm{g} / \mathrm{L}$. It was not clear why this animal had such a high 16 level only at the last time point. No difference was observed between the $17 \beta N T$ 17 levels in the urine of the treated and control barrows. This may be due to the sampling 18 schedule which was once a month and approximately two weeks after the day of 19 treatment. In practice occasionally barrows and gilts are observed with high levels of 20 urinary $17 \beta \mathrm{NT}$, but possibly after treatment levels are only high in urine for a few 21 days. In future experiments we have planned to investigate the kinetics of $17 \beta N T$ in

22 urine from hour to hour and from day to day after treatment. Another possibility is to 23 examine the possible differences in metabolite profiles in treated and non-treated 24 animals. 
1 In boars high levels up to $400 \mu \mathrm{g} / \mathrm{L}$ of $17 \beta \mathrm{NT}$ were observed in urine, especially in

2 older animals (table 3). Analysis of urine was in this trial not able to differentiate

3 between treated and non-treated barrows, but most boars showed much higher levels

4 than barrows.

$5 \quad$ Insert table 3

$6 \quad$ Residue analysis in hair

7 In hair we measured the intact ester of $17 \beta N T$ phenylpropionate. Hair was also

8 sampled at 4 time points. For this method a calibration series was used from

90 to $25 \mu \mathrm{g} / \mathrm{kg}$. All values above this series are estimated (table 4).

11 In all non-treated barrows the levels were low <LLQ. All boars showed levels <LLQ.

12 In non-treated animals no esters were expected in the hair, these results confirmed this

13 expectation. The treated animals showed from the start of the trial high levels $17 \beta N T$

14 phenyl propionate in the hair, ranging from 15 to $220 \mu \mathrm{g} / \mathrm{kg}$, which increased in time

15 reaching a maximum level of $600 \mu \mathrm{g} / \mathrm{kg}$ (fig. 6).

16

17 We conclude that analysis of $17 \beta$ NT phenyl propionate in hair is a good method to

18 detect treated animals.

19 Insert table 4 and figure 6

\section{Conclusion}

22 In this experiment we showed that $17 \beta N T$ phenyl propionate is anabolic in barrows in

23 the dosage used and that this treatment yields increased size and weight of the

24 bulbourethral gland and profound histological alterations in the prostate en

25 bulbourethral gland making them resemble the glands of boars. Inspection of the 
1 weight and histology of bulbourethral glands could be used as a screening method for

2 illegal treatment of barrows with androgenic hormones in the slaughterhouse.

3 Treatment of barrows with $17 \beta \mathrm{NT}$ phenyl propionate can be detected by hair analysis

4 for the intact $17 \beta \mathrm{NT}$ esters. More investigation is needed to evaluate the excretion of

$5 \quad 17 \beta \mathrm{NT}$ phenyl propionate in urine after treatment and the incorporation of $17 \beta \mathrm{NT}$

6 phenyl propionate in hair after treatment in barrows as well as in gilts.

7

8 Acknowledgement

9 This project was financially supported by the Dutch Ministry of Economic Affairs, 10 Agriculture and Innovation.

\section{References}

13

14 Bancroft JD, Stevens A. (eds) 1990. Theory and practice of histological techniques, 15 Churchill Livingstone, Edinburgh, London.

16

17 Booth WD. 1980. A study of some major testicular steroids in the pig in relation to 18 their effect on the development of male characteristics in the prepubertally castrated 19 boar. J Reprod Fert., 59: 155-162.

21 Brandes D. (ed.) 1974. Male accessory sex organs structure and function in mammals, 22 Academic Press, New York, London.

24 Council Directive 96/22/EC, 1996. Official Journal of the European Communion, 25 L125: 3-9. 
2 Debruyckere G, Van Peteghem C, De Brabander HF, Debackere M. 1990. Gas

3 chromatographic-mass spectrometric confirmation of 19-nortestosterone in the urine

4 of untreated boars--effect of the administration of Laurabolin. Vet Q. 12: 246-250.

5

6 De Wilde RO, Lauwers J. 1984. The effect of parenteral use of estradiol,

7 progesterone, testosterone and trenbolone on growth and carcass composition in pigs.

8 J Anim Sci. 59: 1501-1509.

9

10 Duffy E, Rambaud L, Le Bizec B, O'Keeffe M. 2009. Determination of hormonal

11 growth promoters in bovine hair: comparison of liquid chromatography-mass

12 spectrometry and gas chromatography-mass spectrometry methods for estradiol

13 benzoate and nortestosterone decanoate. Anal Chim Acta 637: 165-172.

14

15 Field RA. 1971. Effect of castration on meat quality and quantity. J Anim Sci. 32:

$16 \quad 849-858$.

17

18 Houghton E, Copsey J, Dumasia MC, Haywood PE, Moss MS, Teale P. 1984. The

19 identification of C-18 neutral steroids in normal stallion urine. Biomed Mass

20 Spectrom. 11:96-9.

21

22 Knudson BK, Hogberg MG, Merkel RA, Allen RE, Magee WT. 1985. Developmental

23 comparisons of boars and barrows: I. Growth rate, carcass and muscle characteristics.

24 J Anim Sci. 61: 789-796.

25 
1 Lauwers H. 1984. Morfologische detectie van hormoongebruik bij mestdieren.

2 Vlaamsch Diergeneeskundig Tijdschr. 53: 366-379.

3

4 Lauwers H, Simoens P, De Wilde R, Geest JP, Vos NR. 1983. Effects of anabolic

5 hormones on the genital tract of fattening pigs. Arch Lebensmittelhyg. 34: 133-137.

6

7 López-Bote C, Sancho G, Martínez M, Ventanas J, Gázquez A, Roncero V. 1994.

8 Trenbolone acetate induced changes in the genital tract of male pigs. Zentralbl.

9 Veterinärmed. B. 41: 42-48.

10

11 Mulvaney DR, Marple DN, Merkel RA. 1988. Proliferation of skeletal muscle

12 satellite cells after castration and administration of testosterone propionate Proc SOC.

13 Exper Biol Med. 188: 40-45.

14

15 Nielen MW, Lasaroms JJ, Mulder PP, Van Hende J, van Rhijn JH, Groot MJ. 2006.

16 Multi residue screening of intact testosterone esters and boldenone undecylenate in

17 bovine hair using liquid chromatography electrospray tandem mass spectrometry. $\mathbf{J}$

18 Chromatogr B; Analyt Technol Biomedic Life Sci. 830: 126-34.

19

20 Poelmans S, De Wasch K, Noppe H, Van Hoof N, Van Cruchten S, Le Bizec B,

21 Deceuninck Y, Sterk S, Van Rossum HJ, Hoffman MK, De Brabander HF. 2005.

22 Endogenous occurrence of some anabolic steroids in swine matrices. Food Addit

23 Contam. 9: 808-15. 
1 Prescott JHD, Lamming GE. 1967. The influence of castration on the growth of male

2 pigs in relation to high levels of dietary protein. Anim Prod. 9: 535-545.

3

4 Rico AG. 1985. Metabolism of endogenous and exogenous anabolic agents in cattle. J

$5 \quad$ Anim Sci.57: 226-232.

6

7 Sauer MJ, Samuels TP, Howells LG, Seymour MA, Nedderman A, Houghton E,

8 Bellworthy SJ, Anderson S, Coldham NG. 1998. Residues and metabolism of 19-

9 nortestosterone laurate in steers. Analyst. 123: 2653-2660.

10

11 Scarth J, Akre C, van Ginkel L, Le Bizec B, De Brabander H, Korth W, Points J,

12 Teale P, Kay J. 2009. Presence and metabolism of endogenous androgenic-anabolic

13 steroid hormones in meat-producing animals: a review. Food Addit Contam. Part A 5:

$14 \quad 640-71$.

15

16 Stolker AA, Groot MJ, Lasaroms JJ, Nijrolder AW, Blokland MH, Riedmaier I,

17 Becker C, Meyer HH, Nielen MW. 2009. Detectability of testosterone esters and

18 estradiol benzoate in bovine hair and plasma following pour-on treatment. Anal

19 Bioanal Chem. 395: 1075-87.

20

21 Van Weerden EH, Grandadam JA. 1976. Anabolic Agents in Animal Production.

22 FAO/WHO Symposium Rome, Georg Thieme Verlag, Stuttgart . Chapter: The effect

23 of an anabolic agent on $\mathrm{N}$ deposition, growth and slaughter quality in growing

24 castrated male pigs. p115-122.

25

http://mc.manuscriptcentral.com/tfac Email: fac@tandf.co.uk 
1 Table 1. Body weights at slaughter

\begin{tabular}{|l|c|c|c|}
\hline Body weight (kg) & Boar & Barrow & Barrow 17ß19NT \\
\hline & 116.4 & 103.2 & 113.4 \\
\hline & 123.8 & 116.7 & 120.1 \\
\hline & 119.2 & 114 & 119.2 \\
\hline & 114.3 & 108.3 & 122.5 \\
\hline & 134.1 & 114.1 & 112.3 \\
\hline mean & $121.6^{*}$ & 97.5 & $117.8^{* *}$ \\
\hline s.d. & 7.8 & 109.0 & 4.0 \\
\hline
\end{tabular}

2

3

* Boars significant heavier than barrows $(\mathrm{p}<0.05)$

$4 \quad * *$ Barrow17ßNT significant heavier $(\mathrm{p}<0.05)$ than control barrows

5 Weights barrow17ßNT not significant different than boars

6 


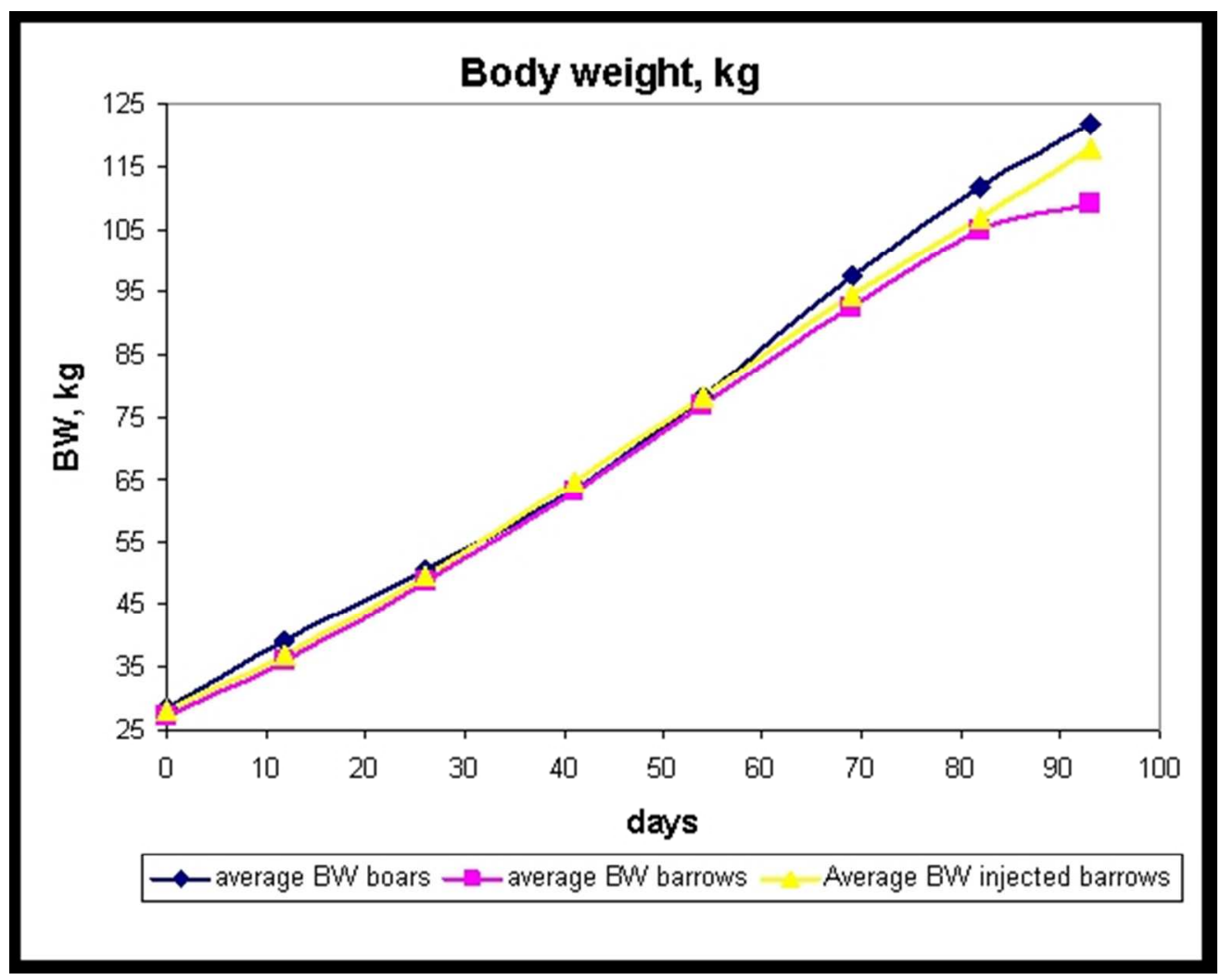

Figure 1. Growth of the animals during the trial $156 \times 124 \mathrm{~mm}(96 \times 96 \mathrm{DPI})$ 
Table 2. Weights of the bulbourethral glands

\begin{tabular}{|c|c|c|}
\hline & $\begin{array}{c}\text { Bulbourethral gland 1 } \\
\text { (grams) }\end{array}$ & Bulbourethral gland 2 \\
\hline Control boar & 69.9 & 65.5 \\
\hline Control boar & 71.7 & 69.2 \\
\hline Control boar & 84.4 & 90.7 \\
\hline Control boar & 69.0 & 66.3 \\
\hline Control boar & 75.7 & 70.6 \\
\hline Mean & $\mathbf{7 3 . 3 * * \pm 8 . 1}$ & $*$ \\
\hline Control barrow & $*$ & 3.9 \\
\hline Control barrow & 4.1 & 3.3 \\
\hline Control barrow & 2.3 & 3.4 \\
\hline Control barrow & 3.6 & 2.8 \\
\hline Control barrow & 3.3 & 3.2 \\
\hline Control barrow & 3.9 & 10.5 \\
\hline mean & $\mathbf{3 . 4 *} \pm 0.5$ & 6.2 \\
\hline barrow17 $\beta 19 N T$ & 9.5 & 10.3 \\
\hline barrow17 $\beta 19 N T$ & 6.4 & 7.9 \\
\hline barrow17 $\beta 19 N T$ & 9.6 & 8.2 \\
\hline barrow17 $\beta 19 N T$ & 6.5 & 11.6 \\
\hline barrow17 $\beta 19 N T$ & 7.0 & \\
\hline barrow17 $\beta 19 N T$ & 11.6 & \\
\hline mean & $\mathbf{8 . 8 *} \pm 2.0$ & \\
\hline
\end{tabular}

* not available

** means of the paired organs 


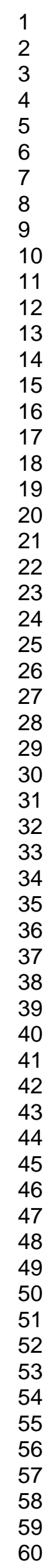




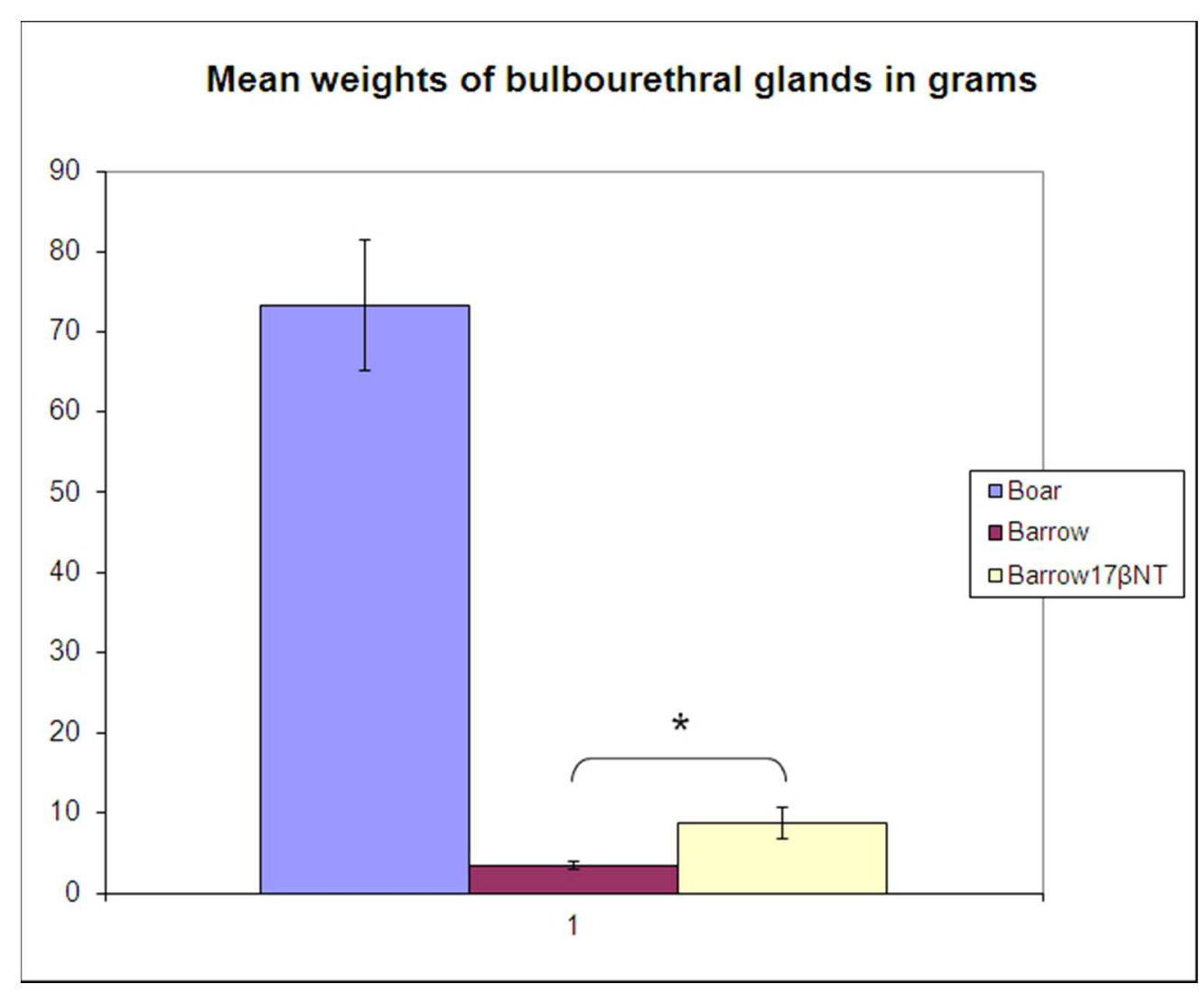

Figure 2: Mean weights of the bulbourethral glands 
Table 3. Levels of 17 $\beta$-19-nortestosterone in urine per animal

Concentration $17 \beta$-19-nortestosterone $(\mu \mathrm{g} / \mathrm{L})$

$(\mathrm{LLQ}=0.5 \mu \mathrm{g} / \mathrm{L}$ for pig urine $)$

\begin{tabular}{|c|c|c|c|c|c|}
\hline Animal & $\mathrm{Sex} /$ & Time point 1 & Time point 2 & Time point 3 & Time point 4 \\
\hline number & treatment & (prior to & & & \\
\hline & & treatment) & & & \\
\hline 1087 & Barrow & 35 & 1 & 5 & 300 \\
\hline 6504 & Barrow & 2 & 2 & 8 & 3 \\
\hline 7630 & Barrow & n.d.* & 1 & 20 & 10 \\
\hline 7702 & Barrow & n.d. & 1 & 13 & 7 \\
\hline 9975 & Barrow & n.d. & 3 & 5 & 10 \\
\hline 9950 & Barrow & n.d. & 2 & 6 & No sample \\
\hline 9373 & Barrow $+* *$ & 12 & 2 & 4 & 4 \\
\hline 8111 & Barrow + & n.d. & 1 & 2 & 3 \\
\hline 5133 & Barrow + & n.d. & 0.5 & 1 & 3 \\
\hline 6185 & Barrow + & n.d. & 2 & 4 & 5 \\
\hline 6559 & Barrow + & n.d. & 2 & 1 & 5 \\
\hline 7177 & Barrow + & 7 & 3 & 3 & 2 \\
\hline 1210 & Boar & 15 & 100 & 125 & 175 \\
\hline 4473 & Boar & 185 & 165 & 150 & 2 \\
\hline 7805 & Boar & - & 130 & 120 & 40 \\
\hline 8775 & Boar & 55 & 140 & 130 & 100 \\
\hline 9631 & Boar & 50 & 80 & 190 & 400 \\
\hline
\end{tabular}


$*$ n.d. $=$ not detected
$* *$ barrow $+=$ barrow $17 \beta 19 \mathrm{NT}$

1

2

3

4

5

6

7

10

11

12

13

14

15

16

17

18

19

20

21

22

23

24

25

26

27

28

29

30

31

32

33

34

35

36

37

38

39

40

41

42

43

44

45

46

47

48

49

50

51

52

53

54

55

56

57

58

59

60 


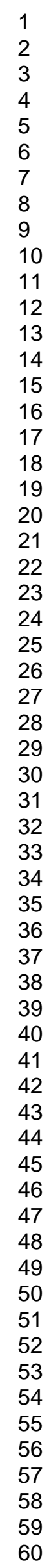


1 Table 4. Levels of 17ß-19-nortestosterone phenylpropionate in hair per animal Concentration 17ß-19nortestosterone phenylpropionate $(\mu \mathrm{g} / \mathrm{kg}),(\mathrm{LLQ}=2.5 \mu \mathrm{g} / \mathrm{kg}$ for pig hair)

\begin{tabular}{|c|c|c|c|c|c|}
\hline Animal & treatment & Time point 1 & Time point 2 & Time point 3 & Time point 4 \\
\hline number & & Prior or & & & \\
\hline & & treatment & & & \\
\hline 1087 & Barrow & $<$ LLQ & $<\mathrm{LLQ}$ & $<$ LLQ & $<$ LLQ \\
\hline 6504 & Barrow & $<$ LLQ & $<$ LLQ & $<$ LLQ & $<$ LLQ \\
\hline 7630 & Barrow & $<$ LLQ & $<$ LLQ & $<$ LLQ & $<$ LLQ \\
\hline 7702 & Barrow & $<$ LLQ & $<$ LLQ & $<\mathrm{LLQ}$ & $<$ LLQ \\
\hline 9950 & Barrow & $<$ LLQ & $<$ LLQ & $<$ LLQ & $<$ LLQ \\
\hline 9975 & Barrow & $<$ LLQ & $<$ LLQ & $<\mathrm{LLQ}$ & $<$ LLQ \\
\hline 8111 & Barrow+* & $<$ LLQ & 17 & 240 & 330 \\
\hline 9373 & Barrow+ & $<$ LLQ & 220 & 15 & 340 \\
\hline 5133 & Barrow+ & $<$ LLQ & 15 & 60 & 200 \\
\hline 6185 & Barrow+ & $<$ LLQ & 365 & 125 & 600 \\
\hline 6559 & Barrow+ & $<$ LLQ & 13 & 175 & 265 \\
\hline 7177 & Barrow+ & $<$ LLQ & 120 & 20 & 90 \\
\hline 7805 & Boar & $<$ LLQ & $<$ LLQ & $<\mathrm{LLQ}$ & $<$ LLQ \\
\hline 8775 & Boar & $<$ LLQ & $<$ LLQ & $<\mathrm{LLQ}$ & $<$ LLQ \\
\hline 9631 & Boar & $<$ LLQ & $<\mathrm{LLQ}$ & $<\mathrm{LLQ}$ & $<$ LLQ \\
\hline 1210 & Boar & $<$ LLQ & $<$ LLQ & $<$ LLQ & $<$ LLQ \\
\hline 4473 & Boar & $<$ LLQ & $<$ LLQ & $<$ LLQ & $<$ LLQ \\
\hline
\end{tabular}


1

2

3

4

5

6

7

8

9

10

11

12

13

14

15

16

17

18

19

20

21

22

23

24

25

26

27

28

29

30

31

32

33

34

35

36

37

38

39

40

41

42

43

44

45

46

47

48

49

50

51

52

53

54

55

56

57

58

59

60

*barrow $+=$ barrow $17 \beta 19 \mathrm{NT}$

2 


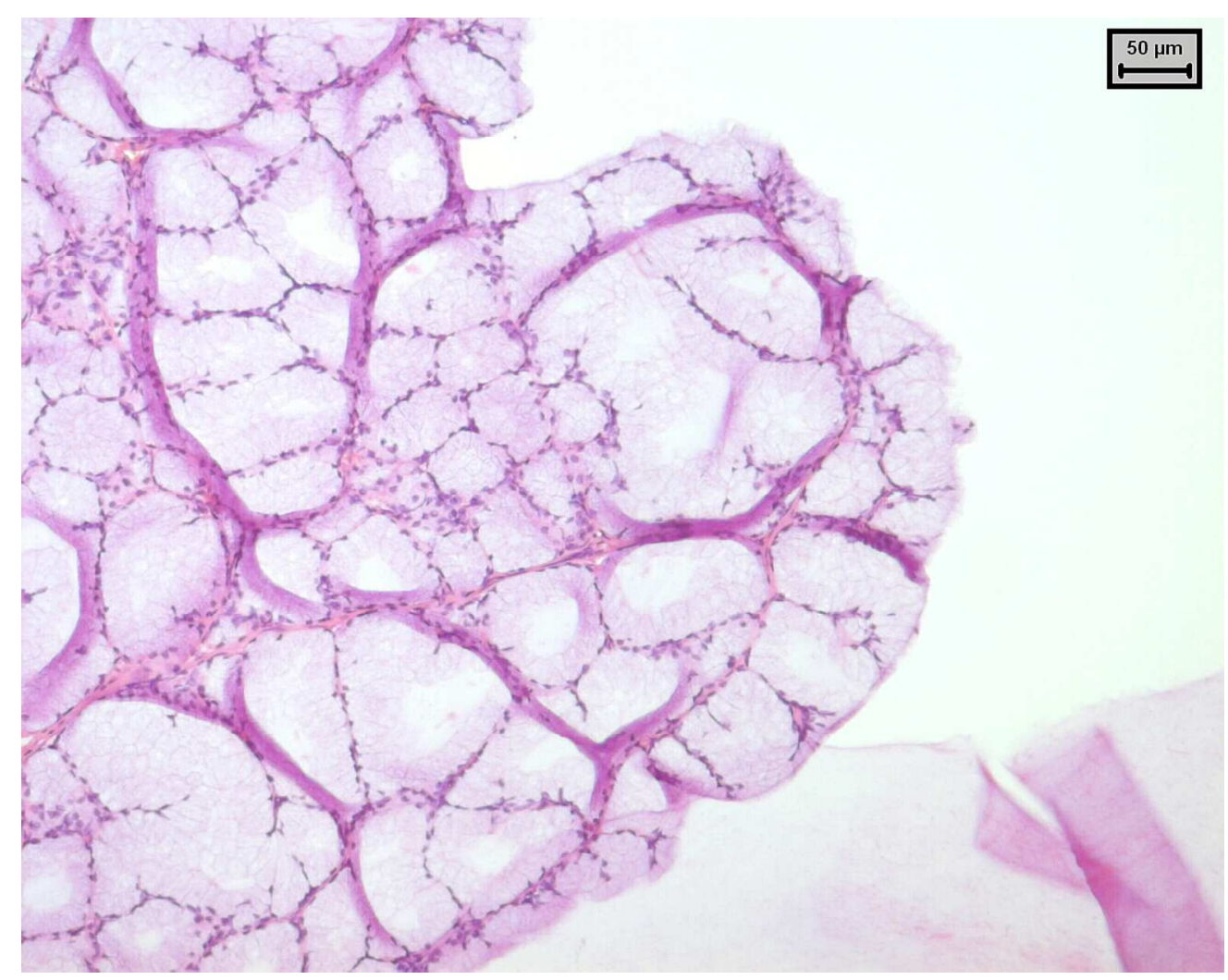

Bulbourethral gland boar (HE), showing mature glandular tissue $343 \times 272 \mathrm{~mm}(96 \times 96 \mathrm{DPI})$ 


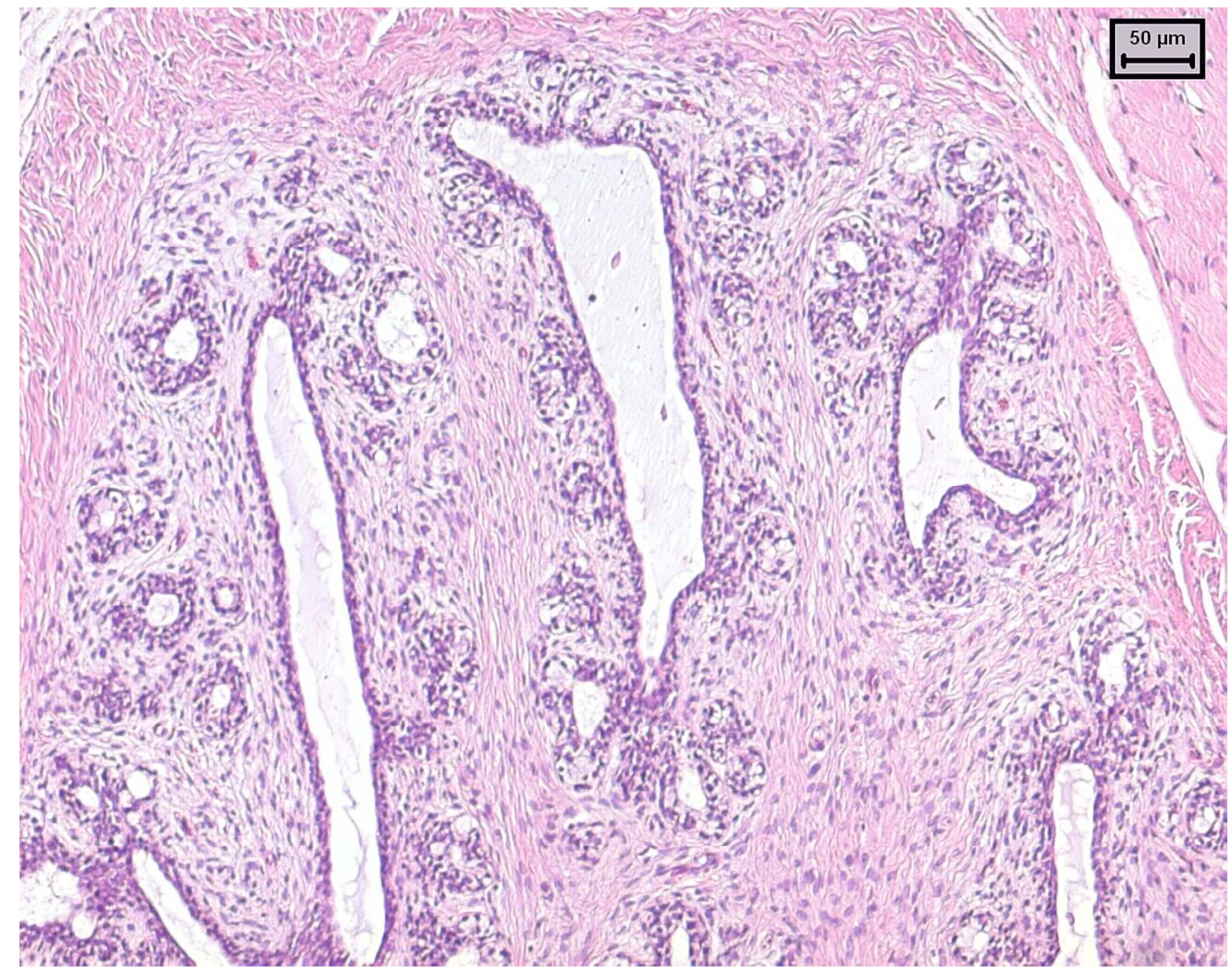

Bulbourethral gland barrow, showing immature glandular tissue (HE) $343 \times 272 \mathrm{~mm}(96 \times 96$ DPI $)$ 


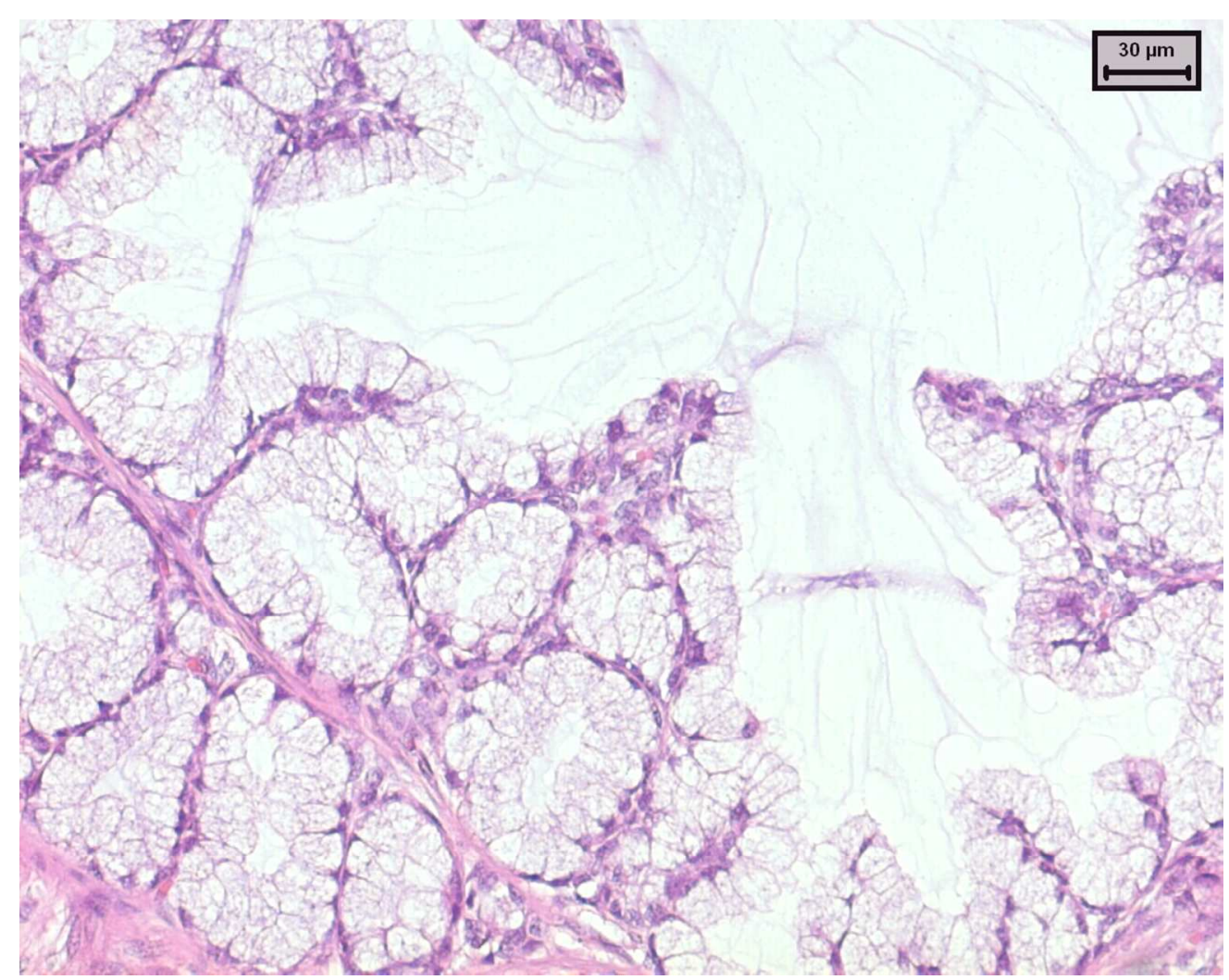

Bulbourethral gland of a treated barrow, showing mature glandular tissue (HE). $343 \times 272 \mathrm{~mm}(96 \times 96 \mathrm{DPI})$ 
Figure 6. $17 \beta N T$ phenylpropionate in hair $181 \times 98 \mathrm{~mm}$ (96 x 96 DPI) 